\title{
Freshwater Zooplankton diversity of Halali reservoir: A Review
}

\author{
Mohd Wasarat $^{1^{*}}$, and Rajendra chauhan ${ }^{2}$ \\ ${ }^{1}$ Department of zoology, Govt. Motilal Vigyan Mahavidyalaya College, Barkatullah University, Bhopal, India \\ ${ }^{2}$ Department of zoology, Govt. Motilal Vigyan Mahavidyalaya College, Barkatullah University, Bhopal, India \\ *Corresponding author: thakkarwasarat28@gmail.com Contact No: 9149520657
}

Available online at: www.isroset.org

Received: 10/Dec/2018, Accepted: 22/Dec/2018, Online: 31/Dec/2018

\begin{abstract}
Investigations on Zooplankton species were conducted monthly using standard methods in Halali reservoir between Mar. 2016 to Feb. 2017. The plankton fauna of the state of madhya pardesh, central India, especially in the Betwa basin, is still poorly known. Thus, this paper presents data from samples taken recently from different sites in Halali. A total of 23 species were recorded, including 13 new occurred rotifers, 07 of cladocerans and 03 of copepods for the state of Halali. The maximum richness was seen for the rotifers, of which the Genus Brachionus have to be highlighted, mainly at the Halali reservoir.
\end{abstract}

Key words: Zooplankton, cladocerans, copepods, Brachionus.

\section{INTRODUCTION}

India is only country with the diverse cultural diversity related with all kinds of climates, rich flora and fauna. In spite of huge volume of hydrosphere only a small portion of it is really available as a resource. $97 \%$ occurs as sea water, whose salinity makes it of no use, while fresh water makes up only $2.6 \%$.

Zooplankton study provides way to be expecting the productivity of fresh water aquatic system $[2,8]$. The biodiversity and distribution of zooplankton in aquatic ecosystem depend mostly on the physico-chemical properties of water. Pollution of water bodies by different sources marks in severe change in zooplankton populations, and thus affects the production possible of the ecosystem [5]. Fresh water ecosystems are the divisions of Earths aquatic system. They include ponds, lakes, streams, rivers, springs and wetland. Limnology deals with the natural productivity of inland water and with all its fundamental influences which determines its causal influences involve physical, chemical, meteorological and biological factors, "which decide the quantity and quality of biological production. Zooplanktons are good quality indicators of vary in water quality because they are highly affected by environmental conditions and by other living species inside water body and respond rapidly to changes in water quality. A variety of zooplanktonic faunal species were found that were usually adapted for the certain conditions of existence. Different groups of the zooplanktons possess their own peak periods of density which is affected by local environmental conditions.

The zooplankton is vital character in the consequences of an aquatic ecosystem and plays an important role in the energy transfer. Freshwater zooplankton plays an important role in ponds, lakes and reservoirs ecosystem and food chain [10]. Approximately all fish depends upon zooplankton for food throughout their larval phases, and some fishs eat zooplankton for their whole lives [7]. Zooplankton forms a chief relation in energy transfer at secondary level in aquatic food webs between heterotrophs and autotrophs [4]. The diversity and distribution of zooplankton in aquatic ecosystem depend generally on the physico-chemical properties of water [5]. The domination of zooplankton in shallow water bodies by cladocera, rotifers and copepods vary according to the degree of organic pollution [11]. Therefore, zooplankton can speak to situation of water body and can be used to review over all lake health. Text on ecology of zooplankton population from various parts of India is existing from the investigation $[6,1,9,10]$.

Reservoirs support rich fish communities and serve as nurseries for most of the commercial fishes. Reservoirs environment received much attention during recent years by ecologists around the world. In the present study, freshwater zooplankton biodiversity in the Halali Reservior at Vidisha, Madhya Pardesh, India was studied monthly wise for the period of one year. 


\section{METHODOLOGY}

For details of zooplankton population surface water samples (100 liters) were filtered with the help of plankton net made of bolting silk of mesh size of $20 \mu \mathrm{m}$ and concentrated samples were preserved with $5 \%$ formaldehyde solution in 100 ml plastic vials. The concentrated samples were examined under the inverted microscope (Metzer made) and identification of plankton was done following the taxonomic references of [3].

\section{Study area}

The dam site is located both in the Raisen and Vidisha districts of Madhya Pradesh, 40 km away from Bhopal on Bhopal vidisha road. The zooplankton biodiversity in the Halali Reservior (Latitude, 12¹8'50" N and Longitude 78 17'59"E) was studied monthly wise basis for a period of one year from March-2016 to April-2017.This lake is constructed across the Betwa river.

\section{Collection of samples}

The zooplankton and water sample were collected from selected three sites for twelve months (one year). Water samples were collected periodically for every month first week during morning hours (7.00 A.M to 9.00 A.M). For quantitative analysis, 100 litres of water was filtered through plankton net made up of bolting silk $(150 \mu \mathrm{m})$ to collect zooplankton. The collected plankton samples were transferred to polyethylene bottles $(90 \mathrm{ml})$ and preserved with $5 \%$ of neutral buffer (10 ml) formalin (aqueous solution of formaldehyde). The plankton samples varied both qualitative (by-towing) as well as quantitative (byfiltering) analysis throughout the study period.

\section{RESULTS AND DISCUSSION}

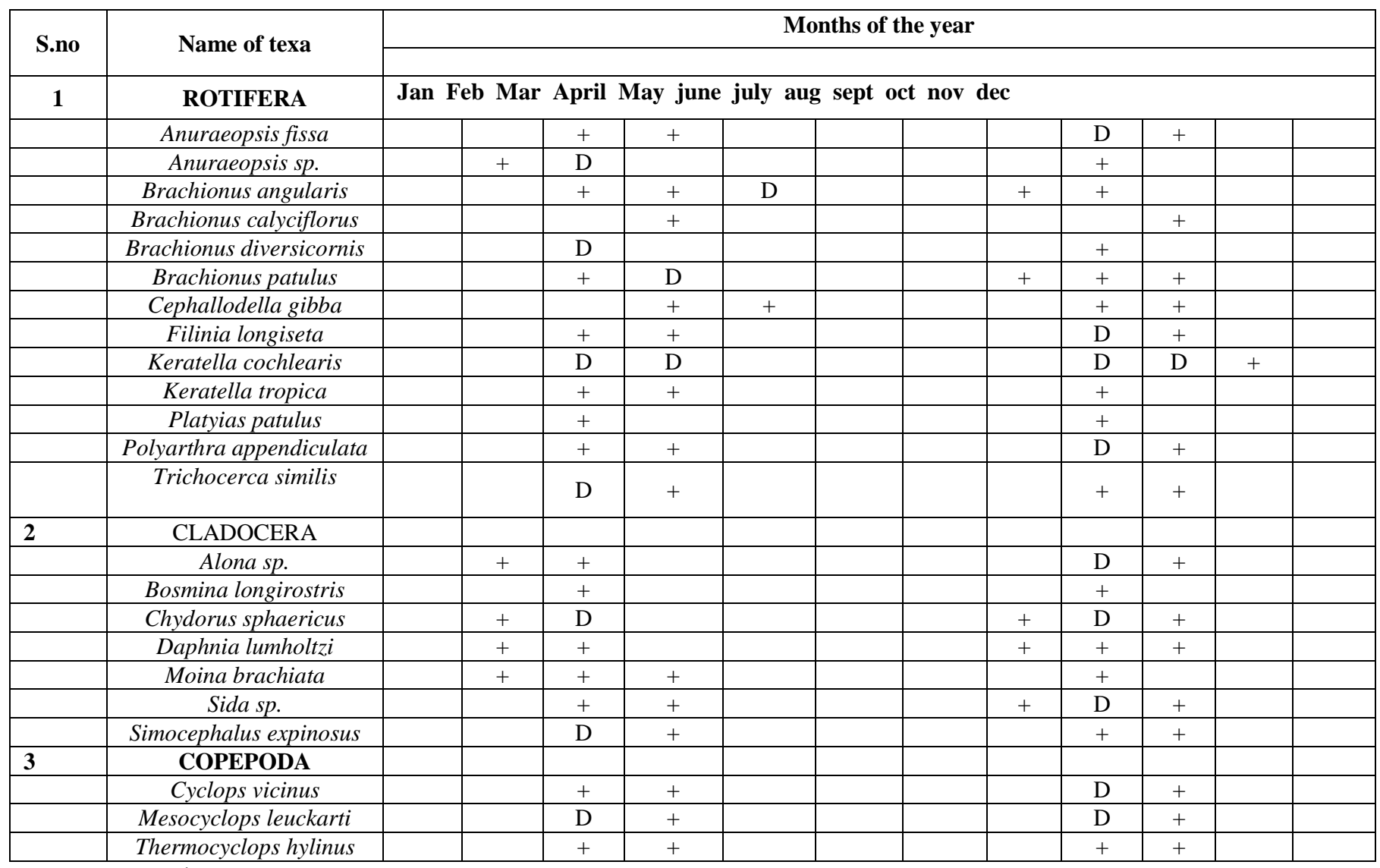

Note: $\mathrm{D}=$ Dominent, $+=$ Present.

Table: Diversity of rotifer, cladocera and copepod in halali reservoir. 
The available zooplankton community is divided into three main groups, these are Cladocera, Copepoda, and Rotifera. Above table represents available zooplankton species and their months of occurrence during the whole study. The Cladocera represents total 07 several genus. These are Chydorus sp., Bosmina sp., Moina sp., Alona sp. Simocephalus sp, Daphnia sp. and Sida sp., Copepoda represents by 3 types of genus, these are Mesocyclops sp. Thermocyclops sp, and Cyclops sp., and Rotifera comprises total 13 types of species. These are Brachionus sp., Keratella sp., Lecane sp., Anuraeopsis sp., Filinia sp. Cephallodella SP. Platyiassp. Polyarthra sp. and Trichocerca sp. Almost in all the seasons' rotifer found to be high except monsoon. During monsoon copepod shows highest density among all the three groups. Copepoda represents lowest density throughout the year.

\section{CONCLUSION}

The above study comprises a good ecological indication of the study area. Availability of several zooplankton species represents a good aquatic environment which is essential for a good water quality. Ecologically reservoirs plays a major role in fish diversity resource. As we know a healthy aquatic environment boosts the growth for aquatics organisms especially for fishes. Hence we can say that the study site found to be in good environmental condition in all aspects. Further studies need to carry out the biochemical profile of zooplanktons. These studies are helpful to conserve and management of reservoirs to increase the species distributions and sustainable production.

\section{REFERENCES}

[1]. Sreenivasan. "The limnology of fish production in two lakes in Chinglipat (Madras)." Hydrobiologia; 32: 131-144. (1967).

[2]. D. Borgmann, H. Shear and J. Moore. "Zooplankton and potential fish production in Lake Ontario" Can. Fish Aquat. Sci. 41:13031309. (1984).

[3]. J.G. Needham and P.R. Needham. “A guide to the study of fresh water biology.” Publishers-Holden-Day, Inc., San Francisco, U.S.A. p.107. (1962).

[4]. K. Deivanai, S. Arunprasath, M.K. Rajan and S. Baskaran "Biodiversity of phyto and zooplankton in relation to water quality parameters in a sewage polluted pond at Ellayirampannai, Virudhunagar District." In: The proceedings of National Symposium on biodiversity resources management and sustainable use, organized by the center for biodiversity and Forest studies, Madurai Kamaraj University. Madurai. (2004).

[5]. K. Harikrishnan and P. K. Abdul Azis. "Ecology of the Neyyar reservoir-A Preliminary report: In proceedings of Kerala Science Congress, Cochin”; 40-145. (1989).

[6]. K. Sivakumar and K. Altaff. "Ecological indices of freshwater copepods and Cladocerans from Dharmapuri District, Tamilnadu, India." Zoo's Print Journal; 19 (5): 1466-1468. (2004).

[7]. L. P. Madin, E. F. Horgan and D.K. Steinberg. "Zooplankton at the Bermuda Atlantic Time-series Study (BATS) station": diel, seasonal and inter annual variation in biomass, 1994-1998. Deep Sea Research;48: 2063-2082. (2001).

[8]. M.D. Morgan, S.T. Threlkeld and C.R. Goldman. "Impact of the introduction of kokanee (Oncorhynchus nerka) and opossum shrimp (Mysis relicta) on a subalpine lake.” J. Fish Res. Bd. Can. 35:1572-1579. (1978).

[9]. N. Manickam, P. Saravana Bhavan, P. Santhanam, P. Chitrarasu and A. Ali. "Jawahar Zooplankton diversity in a perennial freshwater lake. Diversity and Physiological Processes": Ed. Desai PV, Roy R, Goa University. ISBN: 978-81-908791-3-2; 25-37. (2012).

[10]. N. Manickam, P. Saravana Bhavan, P. Santhanam, T. Muralisankar, V. Srinivasan, S. Radhakrishnan, K. Vijayadevan, P. Chitrarasu and A. Jawahar Ali. "Seasonal Variations of Zooplankton Diversity in a Perennial Reservoir at Thoppaiyar, Dharmapuri District, South India." Austin Journal of Aquaculture and Marine Biology; 1(1): 1-7. (2014).

[11]. S.K. Moitra and M.L. Bhowmik. "The seasonal cycles of rotifers in a freshwater fish pond in Kalyani, W. Bengal. In Misra R Gopal B, ed. Proceedings Symposium on Recent Advances in Tropical Ecology.” International Society for Tropical Ecology. Banaras Hindu University. Varanasi; 359. (1968). 